\title{
Evaluation of Osteogenic Potentials of Titanium Dioxide Nanoparticles with Different Sizes and Shapes
}

\author{
Yixing Ren, ${ }^{1}$ Xinxing Feng $\mathbb{D},{ }^{2}$ Xinhua Lang, ${ }^{1}$ Jianbo Wang, ${ }^{3}$ Zhipo Du $\mathbb{D},{ }^{3}$ \\ and Xufeng Niu iD ${ }^{4}$ \\ ${ }^{1}$ Department of Joint Surgery, The Fourth Central Hospital of Baoding City, Baoding 072350, China \\ ${ }^{2}$ Endocrinology and Cardiovascular Disease Centre, Fuwai Hospital, National Center for Cardiovascular Diseases, Chinese Academy \\ of Medical Sciences and Peking Union Medical College, Beijing 100037, China \\ ${ }^{3}$ Department of Orthopaedics, The Fourth Central Hospital of Baoding City, Baoding 072350, China \\ ${ }^{4}$ Research Institute of Beihang University in Shenzhen, Shenzhen 518057, China
}

Correspondence should be addressed to Zhipo Du; duzhipo@163.com and Xufeng Niu; niuxf1979@163.com

Received 26 August 2020; Revised 22 September 2020; Accepted 7 October 2020; Published 11 November 2020

Academic Editor: Xiaoming Li

Copyright (c) 2020 Yixing Ren et al. This is an open access article distributed under the Creative Commons Attribution License, which permits unrestricted use, distribution, and reproduction in any medium, provided the original work is properly cited.

$\mathrm{TiO}_{2}$ nanoparticles (NPs) have the potential to be used in the human body as an artificial implant because of their special physicochemical properties. However, information about the effects of $\mathrm{TiO}_{2} \mathrm{NPs}_{\text {on }}$ preosteoblast proliferation and osteogenic differentiation is not clear. In this work, we focus on the impact of $\mathrm{TiO}_{2} \mathrm{NPs}$ with different shapes and sizes on the proliferation

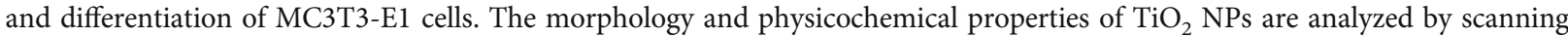
electron microscopy, transmission electron microscopy, Quadrasorb SI analyzer, dynamic light scattering, and zeta potential. The MTT results indicate that when the concentration of $\mathrm{TiO}_{2} \mathrm{NPs}$ is less than $20 \mu \mathrm{g} / \mathrm{mL}$, the proliferation of osteoblasts is preserved the most. The expression of alkaline phosphatase and osteocalcin is detected by BCA and enzyme-linked immunosorbent assay to analyze the differentiation of osteoblasts. The results indicate that both rutile and anatase $\mathrm{TiO}_{2} \mathrm{NPs}$ have a significant inhibiting influence on the differentiation of osteoblasts. Alizarin Red staining is performed on cells to detect the mineralized nodules. The results show that $\mathrm{TiO}_{2}$ NPs can promote the mineralization of MC3T3-E1 cells. Then, we study the oxidative stress response of MC3T3-E1 cells by flow cytometry analysis, and all $\mathrm{TiO}_{2} \mathrm{NPs}$ induce the excessive generation of reactive oxide species. On the other hand, our study also shows that the early apoptotic cells increase significantly. TiO $\mathrm{NPs}_{2}$ are swallowed by cells, and then the agglomerated particles enter mitochondria, causing the shape of mitochondria to change and vacuolation to appear. All these results show that $\mathrm{TiO}_{2} \mathrm{NPs}$ have certain cytotoxicity to cells, but they also promote the mineralization and maturation of osteoblasts.

\section{Introduction}

With the development of nanotechnology, there is a tremendous growth in the application of nanoparticles (NPs) to drug delivery systems, healthcare, antibacterial materials, optics, and electronics $[1,2]$. Compared with fine particles, the interest in NPs is mostly due to their special physicochemical properties like higher specific surface area, which enhances their reactivity. Since surface properties, such as energy level, electronic structure, and reactivity, are quite different from interior states, the bioactivity of NPs is consid- ered different from that of the fine size analogue [3]. Therefore, the potential impacts of NPs on cells and tissue have been investigated by many researchers [4-10].

As a member of $\mathrm{NPs}, \mathrm{TiO}_{2} \mathrm{NPs}$ possess similar surface properties to the general NPs. Due to their unique physicochemical properties, $\mathrm{TiO}_{2}$ NPs are widely used as a photocatalyst in solar cells, pigment in paints, corrosion-protective coating in bone implants, etc. [11-14]. Recently, concerns have been raised on the biological response of $\mathrm{TiO}_{2} \mathrm{NPs}$. Ferin et al. [15] reported that ultrafine $\mathrm{TiO}_{2}(\sim 20 \mathrm{~nm})$ accessed the pulmonary interstitium in rat lung and caused 
inflammatory response compared with fine $\mathrm{TiO}_{2}$ at the same mass burden. Kumazawa et al. [16] observed that fine Ti particles $(1-3 \mu \mathrm{m})$ were phagocytized by the neutrophils (about $5 \mu \mathrm{m}$ ) both in vitro and in vivo, and they concluded that the cytotoxicity of Ti particles was dependent on the particle size. Thereafter, $\mathrm{TiO}_{2}$ NPs have been widely investigated to identify the potential toxicity to various cells, such as human fibroblasts, macrophages, and dermal microvascular endothelial cells $[17,18]$. These studies tried to illustrate the cell toxicological influence of $\mathrm{TiO}_{2}$ NPs based on particle sizes [19], surface coatings [20], crystal structures, and doses [21]. However, few studies investigated the impact of $\mathrm{TiO}_{2}$ NPs on cell osteogenic differentiation.

Bone tissue is an extremely dynamic and diverse tissue in the human body. Trauma, injury, infections, and bone extracellular matrix loss are among the most health-threatening problems for humans [22]. Bone tissue engineering is an exciting approach to directly repair bone defects or engineer bone tissue transplantation [23]. A large number of studies on bone tissue engineering have verified the influence of various materials, stress, and other factors on cell proliferation, differentiation [24-29], and mineralization [30-33] in bone tissue. During bone reconstruction, several cell types, especially osteoblasts, colonize the bone defect. Osteoblasts are mostly responsible for bone regeneration because of their ability to secrete a large amount of proteins on the bone matrix surface by their large Golgi apparatus [34]. Owing to the important role osteoblasts play in bone formation, it is of great interest to investigate whether $\mathrm{TiO}_{2}$ NPs could promote cell osteogenic differentiation. In this study, we investigate the influence of concentration, shape, and size of NPs on preosteoblast proliferation and its osteogenic differentiation by coculturing MC3T3-E1 cells with $\mathrm{TiO}_{2}$ NPs. MC3T3-E1 cell proliferation is detected by the CCK-8 kit. Cell apoptosis and reactive oxidative species (ROS) are analyzed by flow cytometry. ALP and OCN are detected to evaluate the differentiation and proliferation of osteoblasts, and the mineralized nodules are stained using Alizarin Red to estimate the mineralization of osteoblasts.

\section{Materials and Methods}

2.1. Materials. The commercial pure $\mathrm{TiO}_{2} \mathrm{NPs}(\mathrm{A} 1, \mathrm{R} 1$, and R2; Wan Jing New Material Co. Ltd.; purity $>99.8 \%$ ) and rutile $\mathrm{TiO}_{2}$ NPs (A2, Beijing Nanchen Technology Development Co. Ltd.) without any coating were used in this study, as shown in Table 1. Minimum Essential Medium Eagle (MEM) was purchased from Gibco Invitrogen (USA). Fetal bovine serum (FBS) was purchased from MDgenics (New Zealand). Penicillin G and streptomycin were purchased from INALCO (USA). Cell counting kit-8 (CCK-8); ALP assay kit; 2,7-dichlorodihydrofluorescein diacetate (DCFH-DA) assay kit; total glutathione assay kit; superoxide assay kit; total superoxide dismutase (SOD) assay kit with WST-1; lipid peroxidation product (malondialdehyde, MDA) assay kit; cell lysis buffer; and BCA protein assay kit were all obtained from Beyotime Institute of Biotechnology (Jiangsu, China). Phenylmethanesulfonyl fluoride (PMSF) was provided by Roche Co. Ltd. The trypsin was purchased from
AMRESCO (USA). The mouse bone gla protein/osteocalcin (BGP/OCN) ELISA kit was provided by Nanjing Jiancheng Bioengineering Institute. Alizarin Red S was obtained from Bellancom Chemistry. Dexamethasone and $\beta$-glycerophosphate were obtained from Sigma-Fluka. L-ascorbic acid was purchased from AMRESCO (USA). All other reagents used in this study were analytical grade.

2.2. Characterization of $\mathrm{TiO}_{2} \mathrm{NPs}$. $\mathrm{TiO}_{2} \mathrm{NPs}$ were suspended in anhydrous ethanol and ultrasonicated for $5 \mathrm{~s} \times 10$ circles at $200 \mathrm{~W}$. The suspension was dipped on the cleaned silicon wafer. The size and shape of $\mathrm{TiO}_{2} \mathrm{NPs}$ were detected by SEM (Hitachi S-4800 SEM). TEM (FEI Tecnai G2 F20 STwin) was used to characterize the microstructure profile of $\mathrm{TiO}_{2}$ NPs. The surface properties for $\mathrm{TiO}_{2}$ NPs such as surface area, average pore diameter, and pore volume were determined under the Quadrasorb SI analyzer (Quantachrome Instruments, USA) by $\mathrm{N}_{2}$ absorption at $77.3 \mathrm{~K}$. To evaluate the dispersion and aggregation status of $\mathrm{TiO}_{2} \mathrm{NPs}$ in aqueous solution, the DLS method was performed by a particle size and zeta potential analyzer (Zetasizer Nano ZS90, Malvern Instruments, UK).

2.3. Sedimental Observation of $\mathrm{TiO}_{2} \mathrm{NPs}$ Suspended in PBS. A series of experiments were set to observe the sediment of the $\mathrm{TiO}_{2}$ NP suspension. The $\mathrm{TiO}_{2}$ NPs were dispersed in fresh sterilized PBS solution at the concentrations of 10,30 , and $100 \mu \mathrm{g} / \mathrm{mL}$, respectively. To disperse the $\mathrm{TiO}_{2}$ NPs, the suspension was ultrasonicated for $5 \mathrm{~s}$ with a $7 \mathrm{~s}$ interval at $200 \mathrm{~W}$ for 10 times (ultrasonic cell disruptor system, Jiangsu, China). Then, the $\mathrm{TiO}_{2} \mathrm{NP}$ suspension was left standing for $12 \mathrm{~h}$. The sediment status was recorded by digital camera (Canon PowerShot S95, Japan). Then, 5, 10, 20, and $30 \mu \mathrm{g} / \mathrm{mL}$ nano- $\mathrm{TiO}_{2}$ suspensions were prepared in PBS. To increase the dispersion of NPs, bovine serum albumin (BSA) was added in PBS with a concentration of $2 \mathrm{mg} / \mathrm{mL}$ (40:1 compared with the weight of $\mathrm{TiO}_{2} \mathrm{NPs}$ ). The $20 \mu \mathrm{g} / \mathrm{mL} \mathrm{TiO}{ }_{2} \mathrm{NPs}$ in MEM was used as a contrast. All $\mathrm{TiO}_{2} \mathrm{NP}$ suspensions were standing for $48 \mathrm{~h}$ to record the status of the sediment.

2.4. Cell Culture. The mouse preosteoblast MC3T3-E1 cells were obtained from the National Platform of Experimental Cell Resources for Sci-Tech (Beijing, China). The cells were incubated in MEM supplemented with $10 \%$ FBS, $100 \mathrm{U} / \mathrm{mL}$ penicillin, and $100 \mu \mathrm{g} / \mathrm{mL}$ streptomycin at $37^{\circ} \mathrm{C}$ in a fully humidified atmosphere containing $5 \% \mathrm{CO}_{2}$ in air. The culture medium was changed every $3 \mathrm{~d}$ until the cells reached 80 $100 \%$ confluence. The cells were seeded in 96-well plates at a density of $8.0 \times 10^{3}$ cells per well in $100 \mu \mathrm{L}$ culture medium to evaluate the cell activity. For other analyses, the cells were seeded in 6-well plates at a density of $2.5 \times 10^{5}$ cells per well in $2 \mathrm{~mL}$ of culture medium. After $70 \%$ confluence, the cells were exposed to four types of nano- $\mathrm{TiO}_{2}$ suspensions. The $\mathrm{TiO}_{2} \mathrm{NP}$ suspension $(1 \mathrm{mg} / \mathrm{mL})$ was freshly dispersed in PBS solution containing $2 \mathrm{mg} / \mathrm{mL}$ BSA. To avoid aggregation, the suspensions were ultrasonicated for $30 \mathrm{~min}$ in sealed sterile tubes. Then, the suspension was diluted by MEM to $20 \mu \mathrm{g} / \mathrm{mL}$. After adding $10 \% \mathrm{FBS}, 20 \mu \mathrm{g} / \mathrm{mL} \mathrm{TiO}_{2} \mathrm{NP}$ suspension was 
TABle 1: Characterization of $\mathrm{TiO}_{2}$ NPs.

\begin{tabular}{|c|c|c|c|c|c|c|c|c|c|}
\hline $\begin{array}{l}\text { Original } \\
\text { no. }\end{array}$ & No. & Crystal & Shape & Size $(\mathrm{nm})$ & $\begin{array}{l}\text { Specific surface } \\
\text { area }\left(\mathrm{m}^{2} / \mathrm{g}\right)\end{array}$ & $\begin{array}{l}\text { Average pore } \\
\text { diameter (nm) }\end{array}$ & $\begin{array}{c}\text { Total pore } \\
\text { volume (cc/g) }\end{array}$ & $\begin{array}{l}\text { Z-Ave } \\
(\mathrm{d} \cdot \mathrm{nm})\end{array}$ & $\begin{array}{c}\text { Zeta } \\
\text { potential } \\
(\mathrm{mV})\end{array}$ \\
\hline 1 & $\mathrm{~A} 1$ & Anatase & $\begin{array}{l}\text { Red blood } \\
\text { cell like }\end{array}$ & 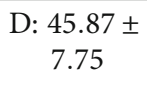 & 97.75 & 1.79 & 0.56 & 166.6 & 5.7 \\
\hline 6 & A2 & Anatase & Sphere & $\begin{array}{c}\mathrm{D}: 79.39 \pm \\
22.58\end{array}$ & 10.37 & 1.93 & 0.05 & 653.3 & -18.7 \\
\hline 2 & $\mathrm{R} 1$ & Rutile & Long rod & $\begin{array}{c}\text { D: } 52.37 \pm \\
7.35 \\
\text { L: } 86.55 \pm \\
12.13\end{array}$ & 21.51 & 2.17 & 0.22 & 408.7 & 2.3 \\
\hline 4 & $\mathrm{R} 2$ & Rutile & Long rod & $\begin{array}{c}\text { D: } 25.46 \pm \\
9.65 \\
\text { L: } 75.34 \pm \\
13.28\end{array}$ & 28.27 & 2.44 & 0.17 & 183.6 & -22.0 \\
\hline
\end{tabular}

cultured with MC3T3-E1 cells. Culture media without $\mathrm{TiO}_{2}$ NPs served as the control in each experiment.

2.5. CCK-8 Assay. The MC3T3-E1 cells were exposed to four types of nano- $\mathrm{TiO}_{2}$ for $24 \mathrm{~h}$, and the concentration of NPs was $20 \mu \mathrm{g} / \mathrm{mL}$. Then, the cells were washed with PBS for 2 times and incubated with $100 \mu \mathrm{L}$ MEM medium and $10 \mu \mathrm{L}$ CCK- 8 at $37^{\circ} \mathrm{C}$ for $2 \mathrm{~h}$. MEM and CCK- 8 without cells were set as the negative control. The intensity was detected using the Varioskan Flash microplate reader (3001, Thermo Fisher Scientific, USA) at $450 \mathrm{~nm}$. Cell viability was expressed as the percentage of viable cells relative to control. All experiments were performed at least in triplicate.

2.6. Determination of ROS Production and Superoxide. The production of ROS was determined by the fluorescence probe DCFH-DA. After being cocultured with four types of $20 \mu \mathrm{g} / \mathrm{mL} \mathrm{TiO}{ }_{2}$ NPs for $24 \mathrm{~h}$, MC3T3-E1 cells were collected. Then, the cells were incubated with $10 \mu \mathrm{M}$ DCFH$\mathrm{DA}$ in the dark for $20 \mathrm{~min}$ at $37^{\circ} \mathrm{C}$ and reverse mixed every 3-5 min to prove the full reaction of the probe with cells. Then, the cells were washed 3 times with serum-free culture medium. The cells cultured with $1 \mu \mathrm{L}$ Rosup served as positive control. The oxidation of DCFH by ROS yields a highly fluorescent compound, $2^{\prime}, 7^{\prime}$-dichlorofluorescein (DCF), which can be analyzed by flow cytometry (BD FACSCalibur, USA). The mean intensity of DCF fluorescence was obtained from 20,000 cells in each experiment group under $488 \mathrm{~nm}$ excitation and $530 \mathrm{~nm}$ emission settings. WST-1 was reduced by superoxide to orange soluble formazan, which was detected at $450 \mathrm{~nm}$. In this kit, the catalase enzyme was added to eliminate the interruption of $\mathrm{H}_{2} \mathrm{O}_{2}$, and SOD was used to exclude the interference and correct the result.

2.7. TEM of MC3T3-E1 Cells. For the TEM study, MC3T3-E1 cells cocultured with or without $\mathrm{TiO}_{2}$ NPs were collected by a cell scraper, then immediately immersed in $2.5 \%$ glutaraldehyde at $4^{\circ} \mathrm{C}$ overnight. After washing with PBS sufficiently, the samples were fixed with $1 \%$ osmium tetroxide, dehy- drated in a graded series of ethanol, embedded in araldite, and polymerized for $24 \mathrm{~h}$ at $37^{\circ} \mathrm{C}$. The ultrathin sections $(60 \mathrm{~nm})$ were cut, stained with uranyl acetate and lead citrate, and then observed with a TEM (Hitachi H-600, Japan) at $50 \mathrm{kV}$.

2.8. Cell Apoptosis Assay. Apoptosis was assessed by Annexin V-FITC and PI staining followed by analysis with flow cytometry. The methodology followed the procedures as described in the Annexin V-FITC/PI detection kit. The cultured cells were exposed to four types of $\mathrm{TiO}_{2} \mathrm{NPs}$ at a concentration of $20 \mu \mathrm{g} / \mathrm{mL}$ for $24 \mathrm{~h}$. Then, the cells were collected by trypsinization, washed with PBS, and centrifuged at $1,000 \mathrm{rpm}$ for $5 \mathrm{~min}$. The cells were resuspended at $1 \times 10^{6}$ cells/mL in Annexin $\mathrm{V}$ binding buffer solution eventually. Aliquots of cells $(100 \mu \mathrm{L} /$ tube $)$ were incubated with $5 \mu \mathrm{L}$ Annexin V-FITC, then mixed and incubated for $15 \mathrm{~min}$ at room temperature in the dark. PI was added to distinguish necrotic cells. Finally, $400 \mu \mathrm{L}$ binding buffer was added to each tube, and the cells were analyzed by flow cytometry within $1 \mathrm{~h}$ of staining.

2.9. Determination of ALP Activity and OCN. ALP was assayed as the release of $p$-nitrophenol from $p$-nitrophenyl phosphate (pNPP) in alkaline buffer as mentioned before. Briefly, cell layers in a 6-well plate were washed 3 times with PBS and then incubated with $100 \mu \mathrm{L}$ cell lysis buffer with $1 \%$ Triton X-100 for 40 min on ice. The cell lysates were removed with a cell scraper placed into an EP tube. After centrifugation at $12,000 \mathrm{rpm}$ for $10 \mathrm{~min}$ at $4^{\circ} \mathrm{C}$, the supernatant was used to determine the enzyme activity. At the same time, the protein content was also detected according to the BCA method. The products of OCN in the culture medium was measured using the method of ELISA. The assays were performed strictly according to the manufacturer's instruction. Briefly, a purified anti-mouse OCN antibody was precoated onto an ELISA microplate. The culture media was concentrated by lyophilization and reconstituted in PBS and pipetted into the wells. All OCN present was bound by the 


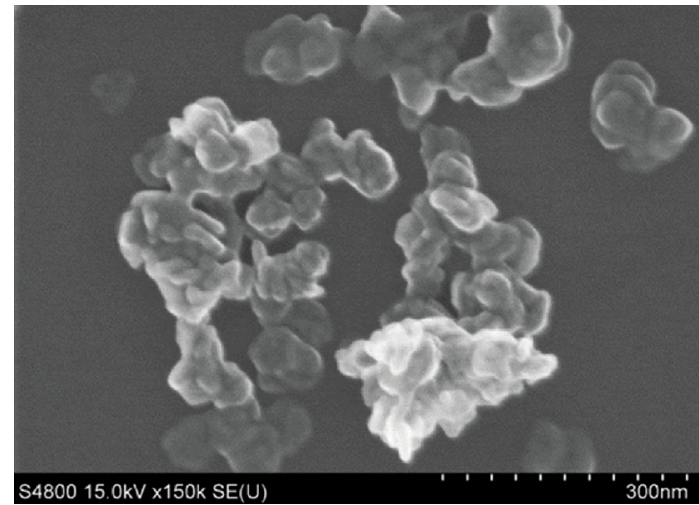

(a)

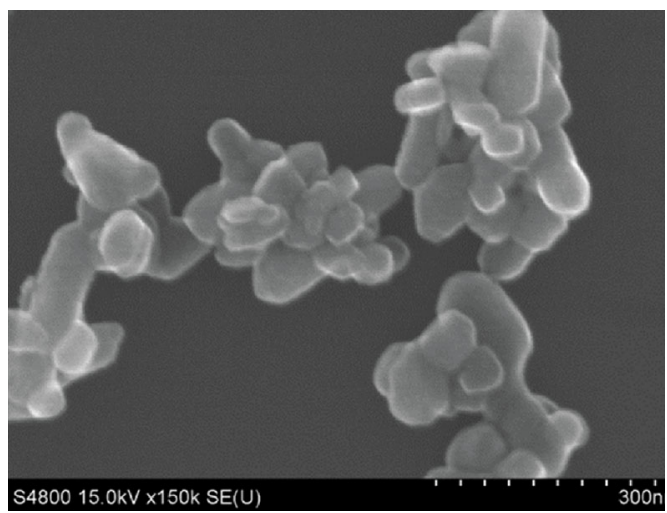

(c)

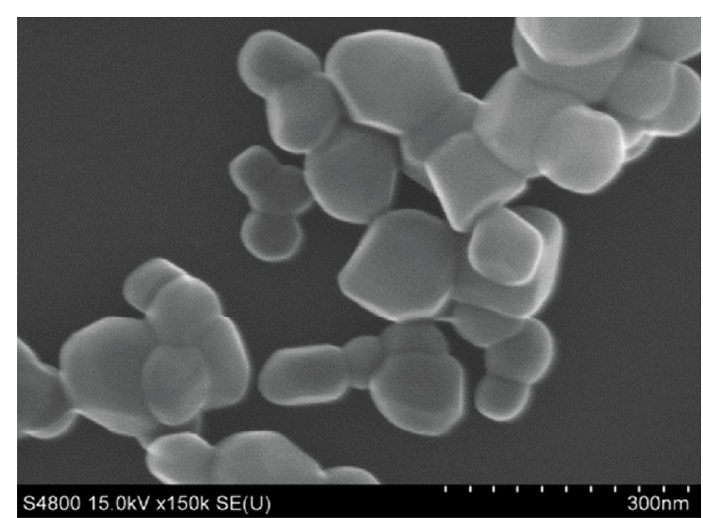

(b)

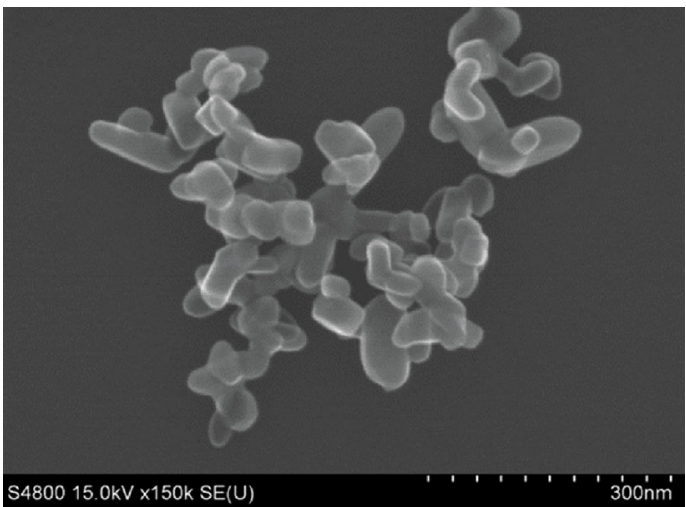

(d)

Figure 1: Micrographs of $\mathrm{TiO}_{2}$ NPs by SEM. (a) The diameter of $\mathrm{A} 1 \mathrm{TiO}_{2} \mathrm{NPs}_{\text {s }} 45.87 \pm 7.75 \mathrm{~nm}$. (b) The diameter of $\mathrm{A} 2 \mathrm{TiO} 2 \mathrm{NPs}$ is $79.39 \pm 22.58 \mathrm{~nm}$. (c) The diameter and length of $\mathrm{R} \mathrm{TiO}_{2} \mathrm{NPs}$ are $52.37 \pm 7.35 \mathrm{~nm}$ and $86.55 \pm 12.13 \mathrm{~nm}$, respectively. (d) The diameter and length of $\mathrm{R} 2 \mathrm{TiO}_{2} \mathrm{NPs}$ are $25.46 \pm 9.65 \mathrm{~nm}$ and $75.34 \pm 13.28 \mathrm{~nm}$, respectively.

immobilized antibody. Polyclonal HRP-conjugated avidin was used to measure the fixation of primary Abs.

2.10. Mineralized Nodule Staining. Alizarin Red S staining was used to evaluate the influence of $\mathrm{TiO}_{2}$ NPs on MC3T3E1 cell mineralization. Briefly, the cells were cultured to $100 \%$ confluence in MEM medium and exposed to four types of $\mathrm{TiO}_{2}$ NPs in the osteogenic medium containing MEM medium and $10 \mathrm{mmol} / \mathrm{L} \quad \beta$-glycerophosphate and $0.05 \mathrm{mmol} / \mathrm{L}$-ascorbic acid. The osteogenic medium was changed every $3 \mathrm{~d}$. At $28 \mathrm{~d}$, the cell layers were washed 3 times with PBS and fixed in $95 \%$ ethanol for $10 \mathrm{~min}$. After being washed 3 times with water, the cells were stained by $0.1 \%$ Alizarin Red S for $30 \mathrm{~min}$. The mineralized nodules were imaged and counted by microscopy.

2.11. Statistical Analysis. All data were reported as mean \pm standard deviation (SD) and analyzed using the SPSS 13.0 (SPSS Inc., USA). Statistical analysis was performed for the experimental data using one-way analysis of variance (ANOVA). Results with $p<0.05$ were considered statistically significant.

\section{Results}

3.1. Characterization of $\mathrm{TiO}_{2} \mathrm{NPs}$. In this study, anatase and rutile $\mathrm{TiO}_{2}$ were provided and characterized in detail. The
SEM and TEM micrographs of $\mathrm{TiO}_{2}$ NPs are shown in Figures 1 and 2. For the anatase $\mathrm{TiO}_{2}, \mathrm{~A} 1$ was like red blood cells (Figure 2(a)) with an average diameter of $45.87 \pm 7.75$ nm (Figure 1(a)). A2 was spherical (Figure 2(b)) with an average diameter of $79.39 \pm 22.58 \mathrm{~nm}$ (Figure $1(\mathrm{~b})$ ). For the rutile $\mathrm{TiO}_{2}, \mathrm{R} 1$ and $\mathrm{R} 2$ were long rods with different sizes (Figures 2(c) and 2(d)). The average length of R1 was 86.55 $\pm 12.13 \mathrm{~nm}$ and the average diameter was $52.37 \pm 7.35 \mathrm{~nm}$ (Figure 1(c)), whereas the average length of R2 was $75.34 \pm$ $13.28 \mathrm{~nm}$ and the average diameter was $25.46 \pm 9.65 \mathrm{~nm}$ (Figure $1(\mathrm{~d})$ ). The physical properties of $\mathrm{TiO}_{2} \mathrm{NPs}$ are well summarized and listed in Table 1.

DLS was used to analyze the aggregation ability of $\mathrm{TiO}_{2}$ NPs in solution. The hydrodynamic diameter distribution of $\mathrm{TiO}_{2} \mathrm{NPs}$ in an aqueous solution is shown in Figure 3. For the rutile $\mathrm{TiO}_{2}$, R1 showed a peak at $408.7 \mathrm{~nm}$ (size distribution from 141 to $1106 \mathrm{~nm}$ ) with a zeta potential of $2.3 \mathrm{mV}$, which suggested that R1 was agglomerated and aggregated easily in solution. R2 showed a narrow peak at $183.6 \mathrm{~nm}$ (size distribution from 105 to $396 \mathrm{~nm}$ ), which indicated that the R2 suspension was stable owing to the zeta potential of $-22.0 \mathrm{mV}$ (Table 1). For anatase, the average diameter of A1 at the peak was $166.6 \mathrm{~nm}$, and A2 showed a high, narrow peak at $235.3 \mathrm{~nm}$ with a low peak at $5.1 \mu \mathrm{m}$. The zeta potentials of the anatase and rutile suspensions are determined and listed in Table 1. 


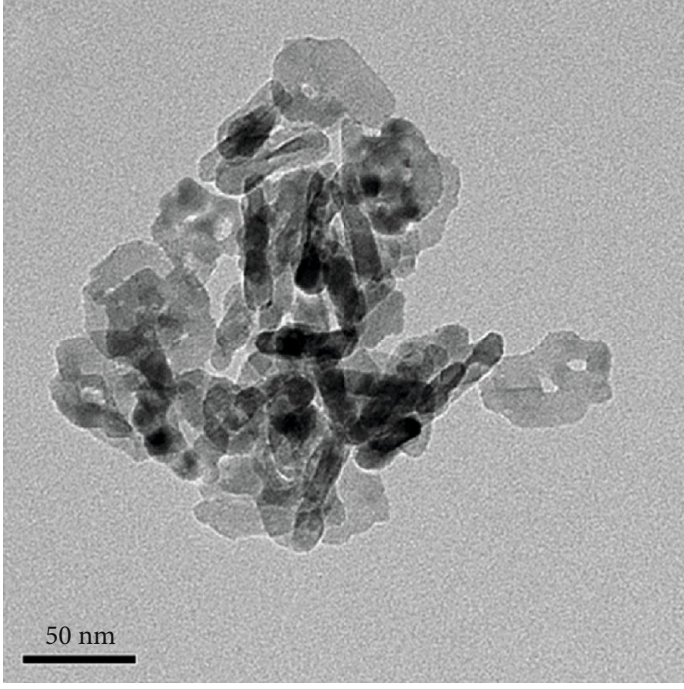

(a)

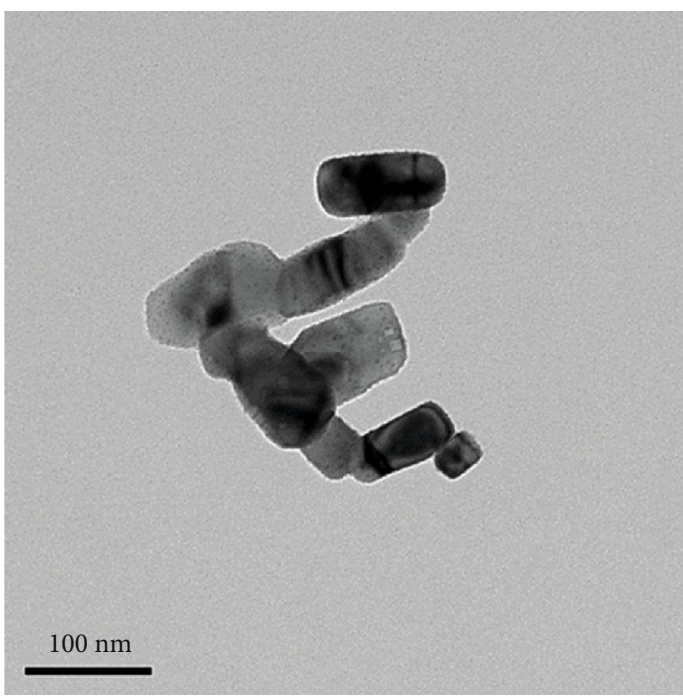

(c)

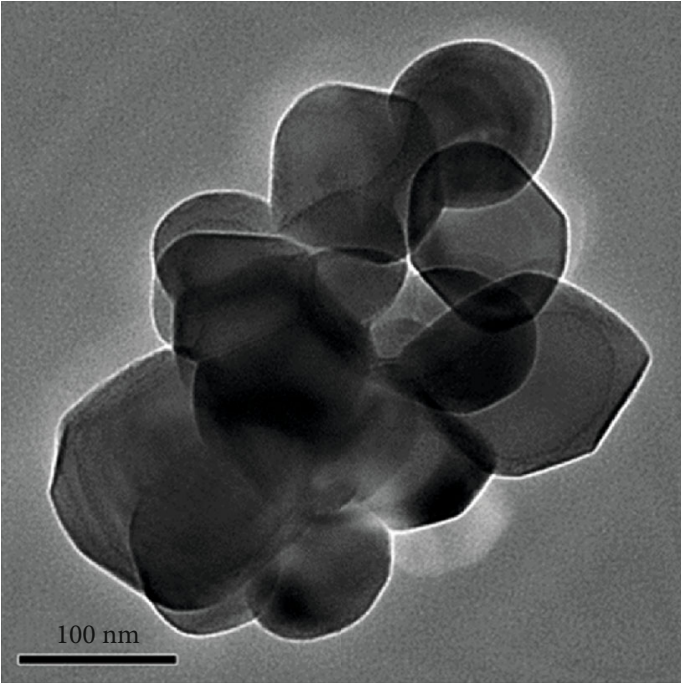

(b)

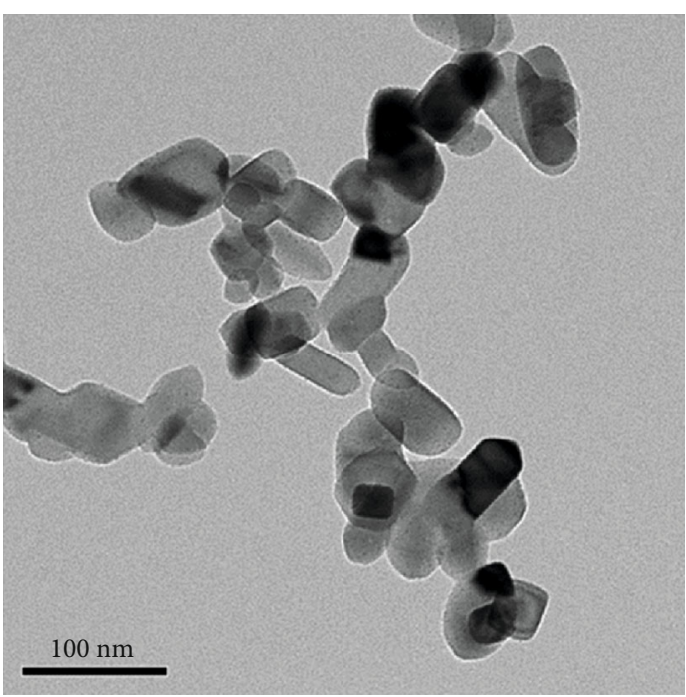

(d)

FIgure 2: Micrographs of $\mathrm{TiO}_{2}$ NPs by TEM: (a) A1 is erythrocyte like; (b) A2 is spherical; (c) R1 is a long rod; (d) R2 is a long rod.

3.2. Determination of $\mathrm{TiO}_{2} \mathrm{NP}$ Concentration. The sedimentation of $\mathrm{TiO}_{2}$ NPs was recorded by camera to select the appropriate concentration used in the experiment. Figure S1 shows the sedimentation of $\mathrm{TiO}_{2}$ at concentrations of 10,30 , and $100 \mu \mathrm{g} / \mathrm{mL}$ in PBS containing BSA for $12 \mathrm{~h}$. The $100 \mu \mathrm{g} / \mathrm{mL} \mathrm{TiO}{ }_{2} \mathrm{NP}$ group was allowed to settle after standing for $2 \mathrm{~h}$. There were some flocculated precipitates in $30 \mu \mathrm{g} / \mathrm{mL} \mathrm{TiO}_{2} \mathrm{NPs}$ at $6.5 \mathrm{~h}$, and the precipitates became obvious at $12 \mathrm{~h}$. However, no sediment was observed in the suspension at the concentration of $10 \mu \mathrm{g} / \mathrm{mL}$ by settling for $12 \mathrm{~h}$.

Figure $\mathrm{S} 2$ is the sedimentation of $\mathrm{TiO}_{2} \mathrm{NPs}$ lower than $30 \mu \mathrm{g} / \mathrm{mL}$ in PBS and culture medium for $48 \mathrm{~h}$. The $20 \mu \mathrm{g} / \mathrm{mL} \mathrm{TiO}_{2}$ NPs in culture medium was set as control. The $30 \mu \mathrm{g} / \mathrm{mL}$ group showed flocculated precipitates at $12 \mathrm{~h}$, whereas no precipitate could be found in $\mathrm{TiO}_{2} \mathrm{NP}$ suspension at a concentration of less than $20 \mu \mathrm{g} / \mathrm{mL}$ after $48 \mathrm{~h}$. This indicated that the suspension with a concentration of less than $20 \mu \mathrm{g} / \mathrm{mL}$ showed good stability and dispersion both in PBS and in culture medium.

3.3. Viability of MC3T3-E1 Cells Cocultured with $\mathrm{TiO}_{2} \mathrm{NPs}$. The cell viability was determined by coculturing MC3T3-E1 preosteoblast cells with $\mathrm{A} 1$ and $\mathrm{R} 2 \mathrm{TiO}_{2} \mathrm{NPs}$ at different concentrations (Figure 4). After $24 \mathrm{~h}$ incubation, cell viability was decreased over $50 \%$ when the concentration of $\mathrm{TiO}_{2}$ NPs was higher than $50 \mu \mathrm{g} / \mathrm{mL}$, and this group also exhibited high cytotoxicity (Figure $4(\mathrm{a})$ ). The cells showed about $80 \%$ viability when the concentration of $\mathrm{TiO}_{2} \mathrm{NPs}$ was between 30 and $50 \mu \mathrm{g} / \mathrm{mL}$, which was significantly lower than the control group (Figure 4(c)). However, when the concentration of $\mathrm{TiO}_{2}$ NPs was lower than $10 \mu \mathrm{g} / \mathrm{mL}$, it had no influence on cell viability (Figure $4(\mathrm{~b})$ ). At $20 \mu \mathrm{g} / \mathrm{mL}, \mathrm{TiO}_{2} \mathrm{NPs}$ also 


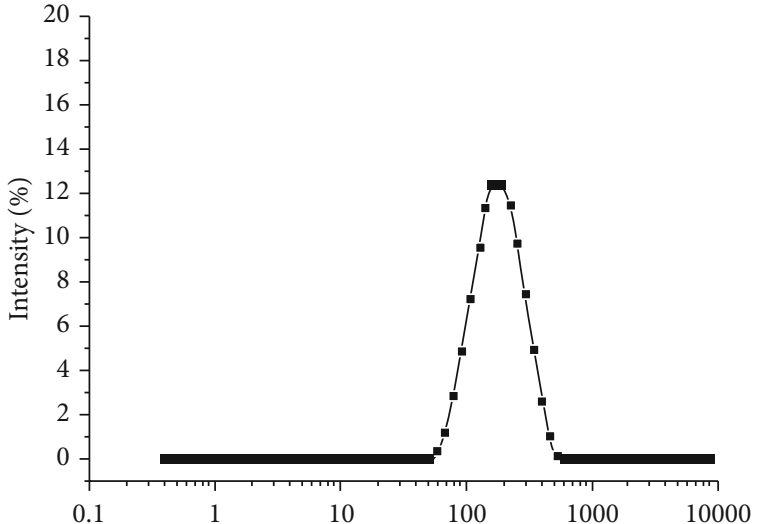

(a)

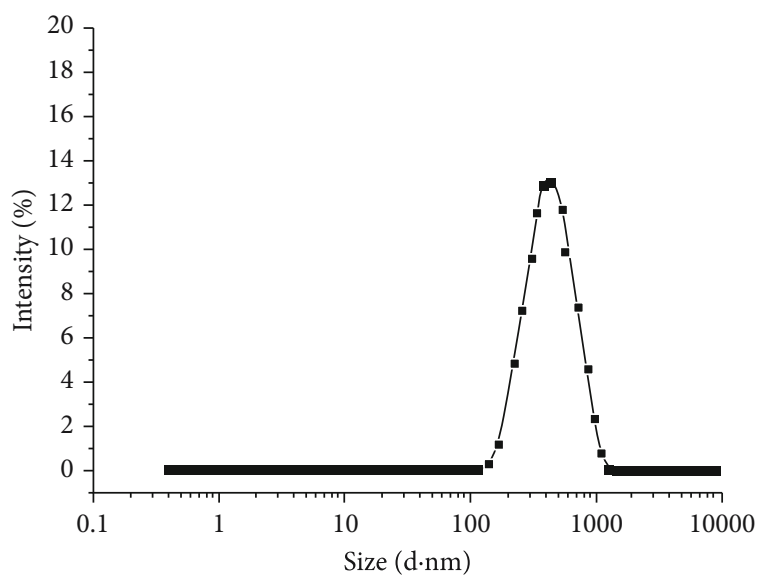

(c)

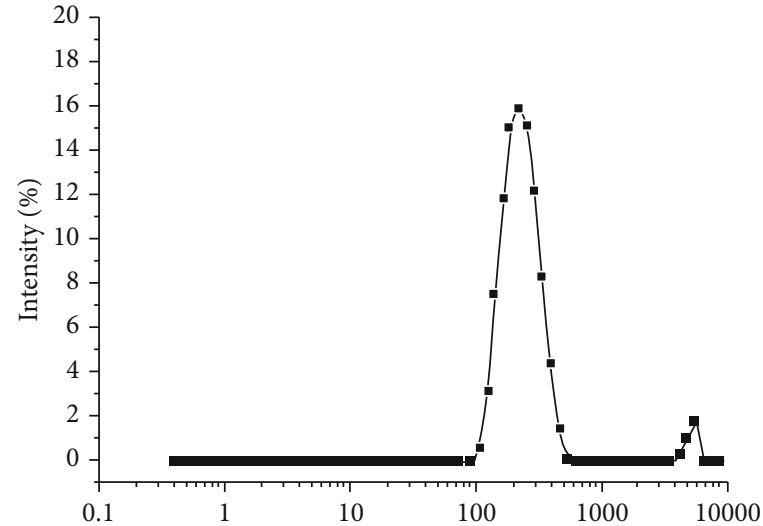

(b)

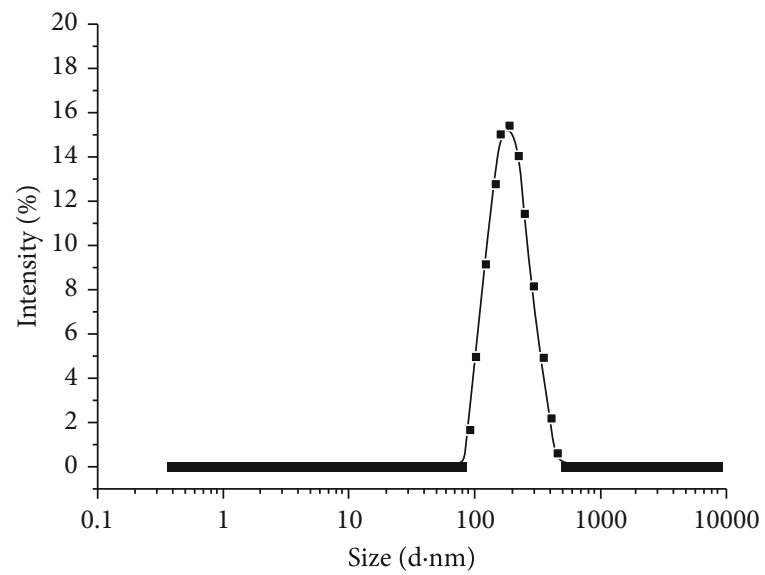

(d)

FIGURE 3: Hydrodynamic diameter distribution of nano- $\mathrm{TiO}_{2}$ in aqueous solution analyzed by the DLS method. (a) The average diameter of A1 at the peak is $166.6 \mathrm{~nm}$. (b) A2 shows a high, narrow peak at $235.3 \mathrm{~nm}$. (c) R1 shows a peak at $408.7 \mathrm{~nm}$. (d) R2 shows a narrow peak at $183.6 \mathrm{~nm}$.

showed no obvious effect on cell viability. These results indicated that $20 \mu \mathrm{g} / \mathrm{mL}$ was a critical value for the cell viability of $\mathrm{TiO}_{2} \mathrm{NPs}$, and different levels of cytotoxicity were shown over this concentration.

\subsection{ALP and OCN Expression of MC3T3-E1 Cells. To find out} the influence of NPs on ALP expression, the MC3T3-E1 cells were cocultured with $\mathrm{A} 1$ and $\mathrm{R} 1 \mathrm{TiO}_{2}$ NPs at concentrations of 20,50 , and $100 \mu \mathrm{g} / \mathrm{mL}$ for 7 and $14 \mathrm{~d}$. Compared with the blank control group, the osteogenic differentiation ability of all experimental groups was significantly decreased (Figure 5(a)). Moreover, $\mathrm{A} 1$ and $\mathrm{R} 1 \mathrm{TiO}_{2} \mathrm{NPs}$ had different degrees of influence on osteoblast differentiation. When the concentration is low, the inhibitory effect on cell differentiation of R1 is less than that of A1. However, with the increase of NP concentration, the inhibitory effect of rutile materials on cell differentiation was gradually stronger than that of anatase materials. The ALP level of cells cocultured with A1 and R1 materials for $14 \mathrm{~d}$ is shown in Figure 5(b). When the concentration of A1 was $20 \mu \mathrm{g} / \mathrm{mL}$, the ALP level was reduced by $64.30 \%$ compared with the control. When the concentration was 50 and $100 \mu \mathrm{g} / \mathrm{mL}$, the ALP level decreased by $43.01 \%$ and $47.69 \%$, respectively. The inhibition effect of R1 on cell differentiation was similar with that of A1. These results indicated that both $\mathrm{A} 1$ and $\mathrm{R} 1$ had negative impacts on the differentiation of preosteoblast cells. As for the results of OCN, there was no significant difference between the experiments groups and the control group (Figure S3).

\subsection{Determination of ROS Production and the Antioxidant} Level. Lots of evidence pointed out that ROS production represented a hallmark in $\mathrm{TiO}_{2} \mathrm{NP}$ toxicity. In this study, ROS production and the antioxidant level in MC3T3-E1 cells were tested and the results are shown in Figure 6. The fluorescence intensity of oxidized DCF increased in cells when treated with $\mathrm{TiO}_{2}$ NPs (Figure 6(a)), which was especially obvious in the A1, R1, and R2 groups $(p<0.05)$. This meant that ROS was generated in response to the treatment of $20 \mu \mathrm{g} / \mathrm{mL} \mathrm{TiO}_{2}$ NPs. In addition, WST1 was used to detect the level of superoxide production in cells. Compared to the control group, four types of $\mathrm{TiO}_{2}$ NPs induced significantly higher superoxide production (Figure 6(b)). Total glutathione (T-GSH), the main 

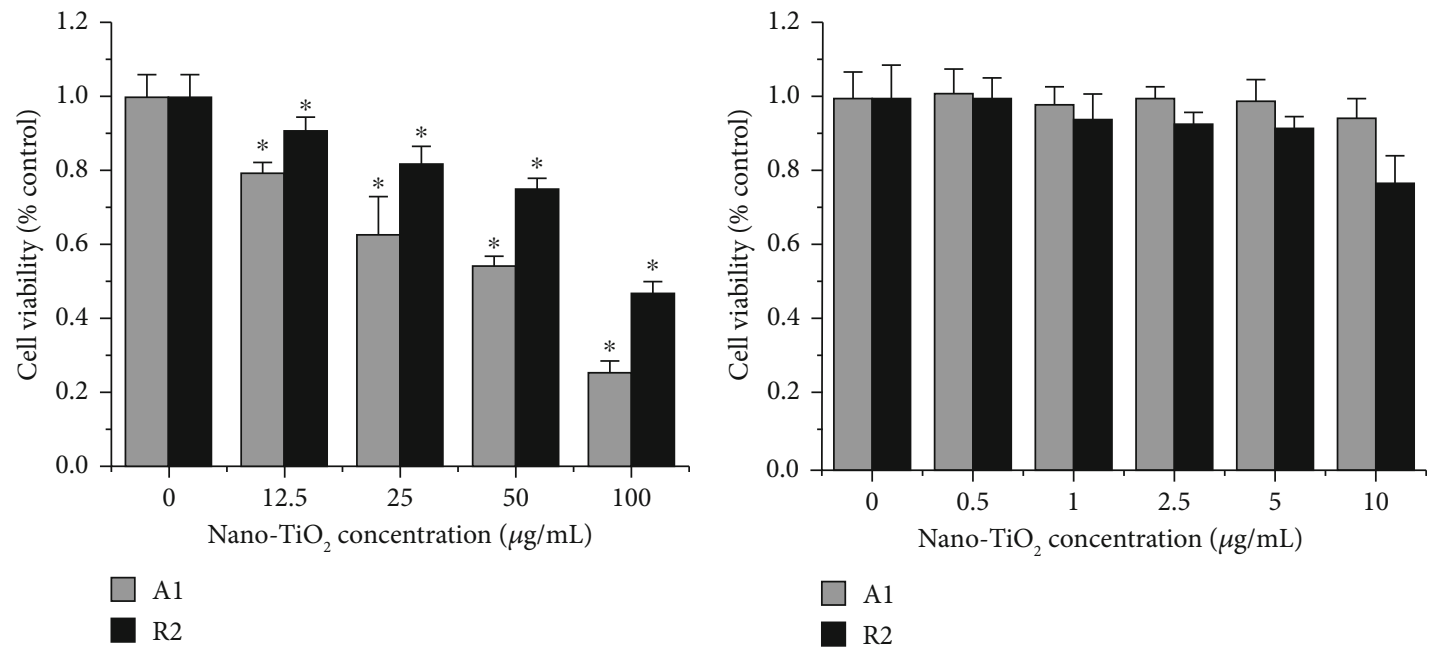

(a)

(b)

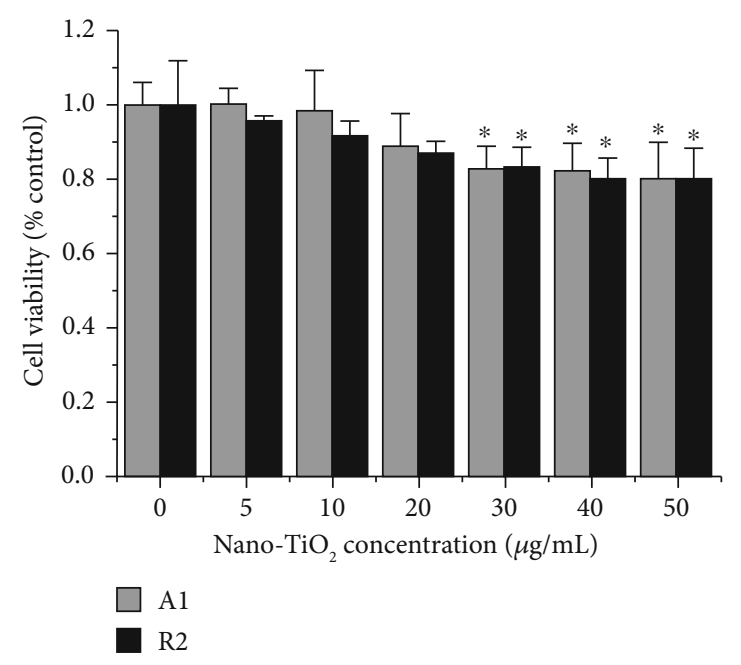

(c)

Figure 4: Cell viability of MC3T3-E1 cells cocultured with different concentrations of $\mathrm{TiO}_{2} \mathrm{NPs}^{*} p<0.05$ significantly different from the corresponding control group.

antioxidant, decreased in $\mathrm{TiO}_{2} \mathrm{NP}$-treated cells, and the significantly downregulated T-GSH was detected in the $\mathrm{A} 1$ and R1 groups (Figure 6(c)). SOD and MDA were also detected to show the level of oxidative stress in MC3T3-E1 cells. After treatment with $\mathrm{TiO}_{2}$ NPs, SOD and MDA activity was slightly higher than that in the control, which was especially obvious for the R1 group $(p<0.05)$ (Figures 6(d) and 6(e)).

\subsection{TEM Characterization of MC3T3-E1 Cells Cocultured} with $\mathrm{TiO}_{2} \mathrm{NPs}$. After coculturing with $\mathrm{TiO}_{2} \mathrm{NPs}$, the membrane of MC3T3-E1 cells was distorted and caved in, enclosing the aggregated $\mathrm{TiO}_{2} \mathrm{NPs}$ (Figure $7(\mathrm{a})$ ). The clustered $\mathrm{TiO}_{2}$ NPs were enclosed by the plasma membrane of cells and internalized into the cytoplasm around cell nucleus (Figure 7(b)). Some NPs were located in the mitochondria, and the internalization of $\mathrm{TiO}_{2} \mathrm{NPs}$ caused the ultrastructural change of MC3T3-E1 cells. The nuclear envelope was distorted though the cell nucleus was clear and intact. Meanwhile, the nuclear chromatin was condensed and distributed over the fringe of the nucleus. The number of mitochondria and lysosome increased, and the lamellar cristae became irregular and disordered. At the same time, mitochondrial structures became swollen and vacuous, suggesting that the storage of nano- $\mathrm{TiO}_{2}$ within mitochondria resulted in some damage to the organelle. The swelling of the golgi complex was also observed (Figure $7(\mathrm{c})$ ), which suggested the injury of the golgi complex. After exposure to A2 and R2 for $24 \mathrm{~h}$, cell disintegration and an apoptotic body appeared (Figures $7(\mathrm{~d})$ and $7(\mathrm{e})$ ). The TEM results indicated that $\mathrm{TiO}_{2} \mathrm{NPs}$ were absorbed in the cells and induced some injury at the subcellular level.

3.7. Cell Apoptosis and Mineralized Nodules of MC3T3-E1 Cells Cocultured with $\mathrm{TiO}_{2}$ NPs. MC3T3-E1 cell apoptosis and necrosis were observed by flow cytometry 


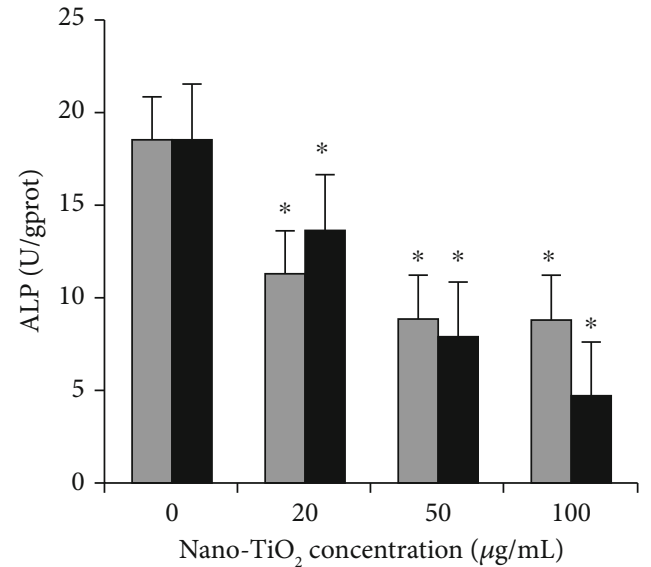

$\square \mathrm{Al}$

R1

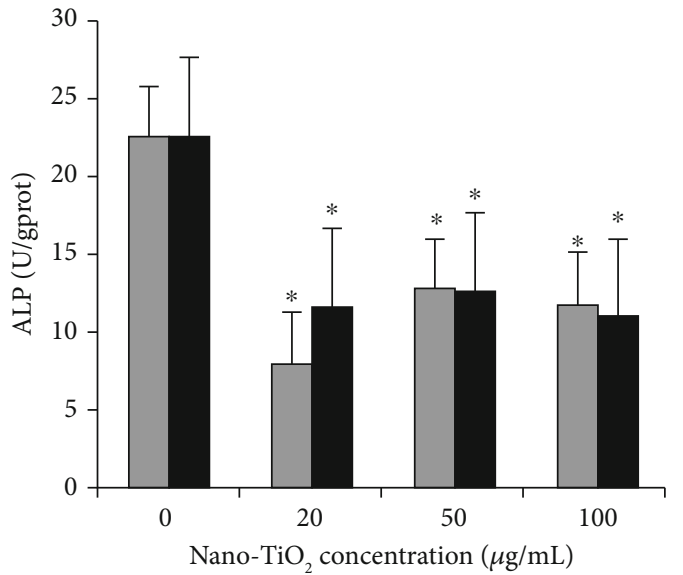

$\square \mathrm{A} 1$

口1

(a)

(b)

Figure 5: ALP expression of MC3T3-E1 cells cocultured with $\mathrm{TiO}_{2} \mathrm{NPs}_{\text {for }} 7 \mathrm{~d}$ (a) and $14 \mathrm{~d}(\mathrm{~b}) .{ }^{*} p<0.05$ significantly different from the corresponding control group.

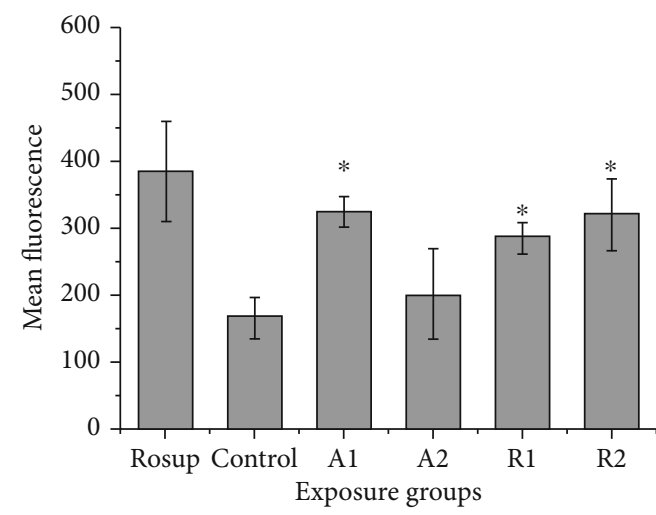

(a)

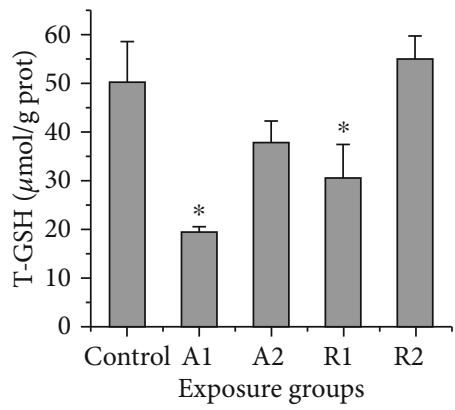

(c)

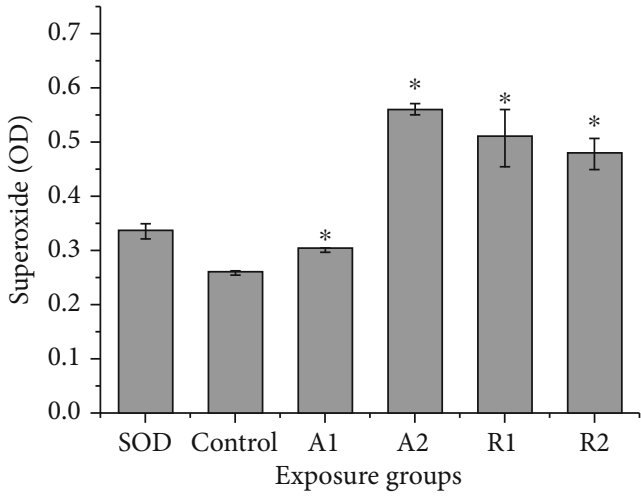

(b)

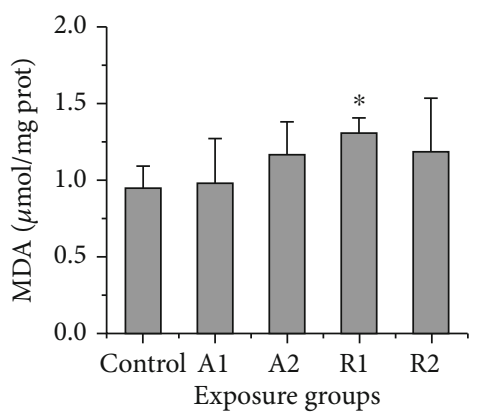

(e)

FIgure 6: Oxidative stress in MC3T3-E1 cells treated with nano- $\mathrm{TiO}_{2}$ for $24 \mathrm{~h}$ by measuring the levels of (a) ROS, (b) superoxide production, (c) total glutathione (T-GSH), (d) SOD, and (e) MDA. Data are expressed as mean \pm SD of three repeated experiments. ${ }^{*} p<0.05$; significantly different from the control group. 


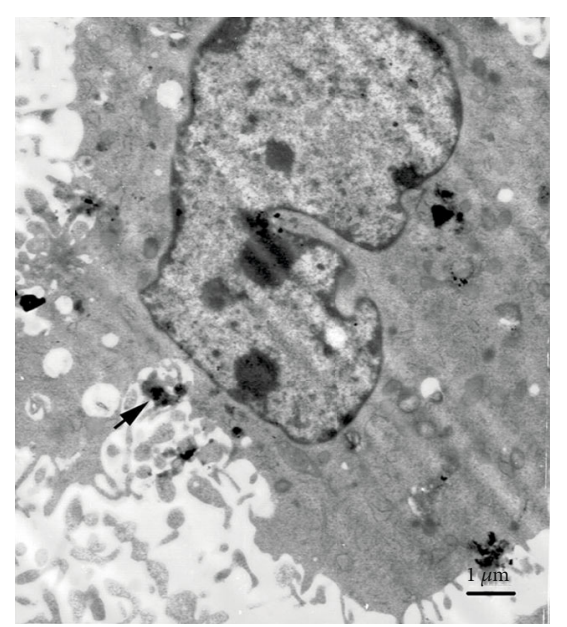

(a)

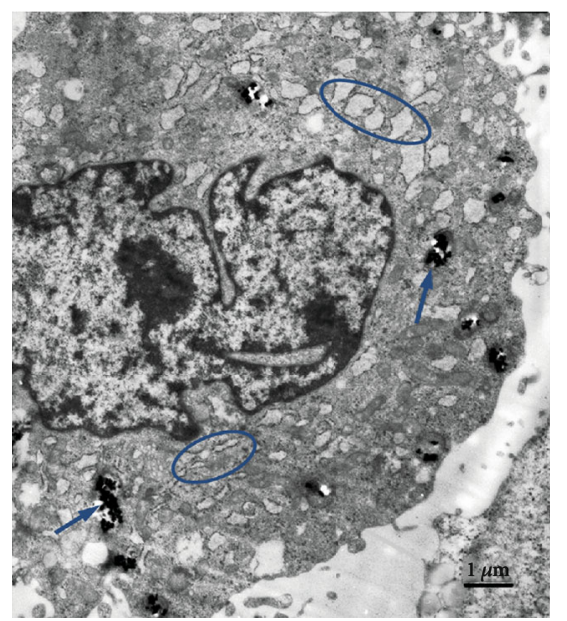

(c)

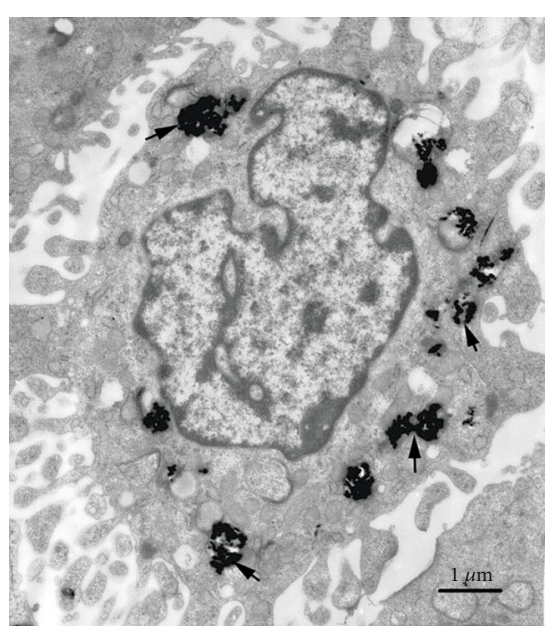

(b)

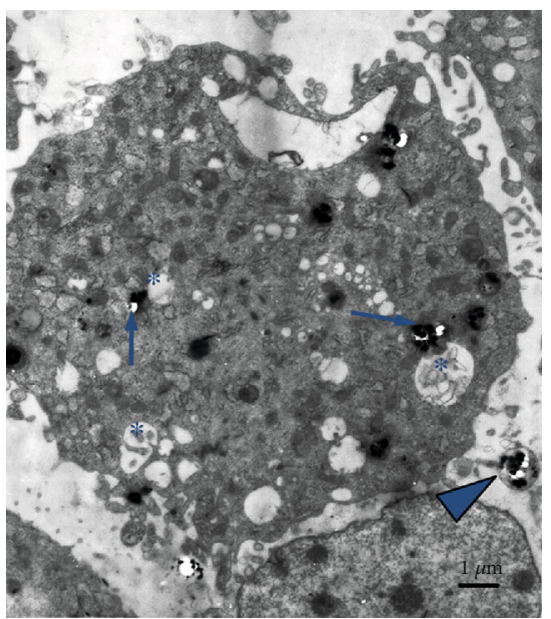

(d)

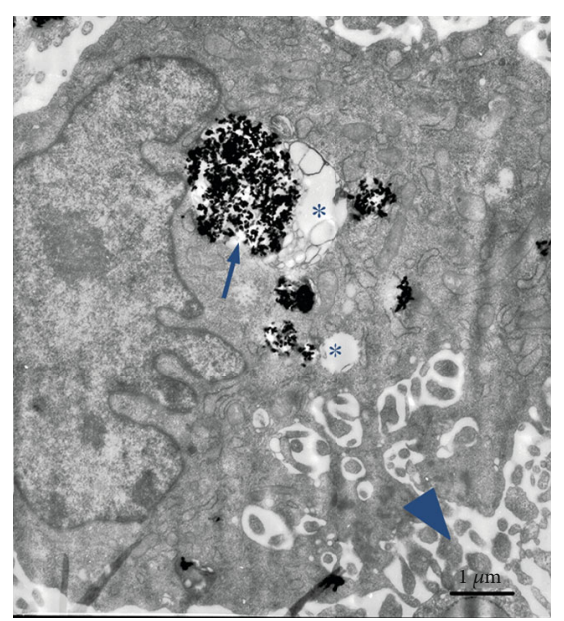

(e)

Figure 7: The ultrastructure morphology of MC3T3-E1 cells after exposure to $\mathrm{TiO}_{2} \mathrm{NPs}_{\text {for }} 24 \mathrm{~h}$. $*$ indicates the swelling of mitochondria and vacuolization. $\nearrow$ indicates the internalization of $\mathrm{TiO}_{2} \mathrm{NPs}$ and aggregation in the cytoplasm. $O$ indicates the swelling of the golgi complex. $\boldsymbol{\Delta}$ indicates the apoptotic body. 
quantitatively. As shown in Figure 8, after exposure to the four types of $\mathrm{TiO}_{2} \mathrm{NPs}$, the percentage of cells in early apoptosis increased by $130.37 \%$ (A1), $81.38 \%$ (A2), $99.63 \%$ (R1), and $116.11 \%$ (R2) compared to the control group, respectively. Moreover, the percentage of cells in late apoptosis and necrosis in the exposure groups was significantly higher than that in the control group. However, it is worth noting that the majority of the cells were alive. The percentage of live cells was $88.64 \%$ in the control group, and the percentage in the exposure groups remained at the level of about $80 \%$. This was consistent with the result obtained by the CCK- 8 method.

After $28 \mathrm{~d}$ of culture with differential medium, the mineralized nodules were stained with Alizarin Red S (Figure 9). The mineralized nodules could be found in all groups, which increased significantly in $\mathrm{TiO}_{2} \mathrm{NP}$-exposed groups. These results indicated that $\mathrm{TiO}_{2}$ NPs promoted osteoblast mineralization and maturation.

\section{Discussion}

In this study, we selected anatase and rutile $\mathrm{TiO}_{2} \mathrm{NPs}$ as test nanomaterials. MC3T3-E1 preosteoblast cells were used as tested cells to evaluate the influence of $\mathrm{TiO}_{2} \mathrm{NPs}$ with different sizes and shapes on bone formation. Firstly, the sizes and shapes of $\mathrm{TiO}_{2}$ NPs were evaluated by SEM and TEM. The anatase nanomaterials were like red blood cells with a diameter of $45.87 \pm 7.75 \mathrm{~nm}$ and had a spherical shape with a diameter of $79.39 \pm 22.58 \mathrm{~nm}$. Some studies found that the same materials with different sizes have a different influence on cell formation [35]. It is generally believed that the particles with sizes smaller than $10 \mu \mathrm{m}$ are easily swallowed by cells, while those with sizes bigger than $10 \mu \mathrm{m}$ are more likely to be circumvoluted by macrophages. Based on this, we predicted that the nanomaterials can be swallowed by preosteoblasts and influence the cells. According to the results of the NP suspension precipitation experiment, we found that material concentrations below $30 \mu \mathrm{g} / \mathrm{mL}$ can guarantee no precipitation for $24 \mathrm{~h}$. By measuring the effects of different concentrations of $\mathrm{TiO}_{2}$ NPs on cell proliferation, we determined that the optimum material concentration for experiments is $20 \mu \mathrm{g} / \mathrm{mL}$, which not only conforms with the actual range of material concentration in the physical environment but also ensures that $\mathrm{TiO}_{2} \mathrm{NP}$ precipitation does not occur after $24 \mathrm{~h}$.

Osteoblast is the main cell type participating in bone formation, which is responsible for synthesis, secretion, and mineralization of the bone matrix. Bone is constantly reconstructed, and the bone reconstruction process is maintained by the cooperation of osteoblasts and osteoclasts. The balance between osteoblasts and osteoclasts is the key to maintaining normal bone mass. It was found that particles from high molecular polyethylene wear can inhibit the proliferation and differentiation of osteoblasts [36]. We find the same trend in the process of cocultivation of $\mathrm{TiO}_{2} \mathrm{NPs}$ and osteoblasts. By cell proliferation tests, we can find that if the concentration of $\mathrm{TiO}_{2}$ NPs is lower than $50 \mu \mathrm{g} / \mathrm{mL}$, the osteoblast proliferation is significantly impaired as the particle concentration increases. Once the concentration of $\mathrm{TiO}_{2}$

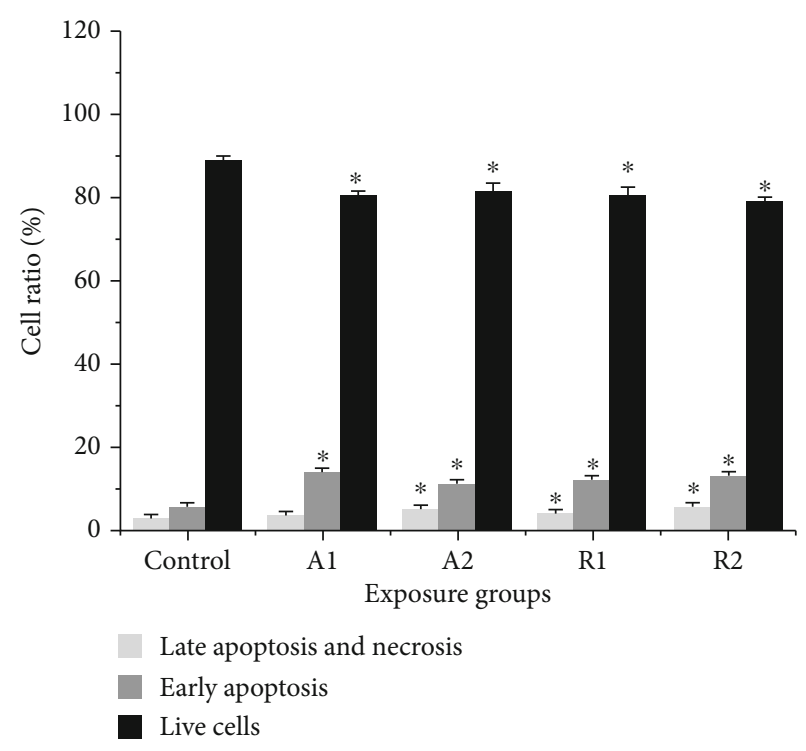

Figure 8: Cell apoptosis and necrosis detected by flow cytometry after being treated with nano- $\mathrm{TiO}_{2}$ for $24 \mathrm{~h} .{ }^{*} p<0.05$; significantly different from the control group.

NPs is less than $10 \mu \mathrm{g} / \mathrm{mL}$, the NPs do not produce a dose effect on cells. We reckon that cell proliferation ability does not show an obvious change when the material concentration is too low. Besides, when the concentration of $\mathrm{TiO}_{2} \mathrm{NPs}$ is in the range of $10-50 \mu \mathrm{g} / \mathrm{mL}$, the dose effect on cells appears at a slower trend. The comprehensive results show that $\mathrm{TiO}_{2} \mathrm{NPs}$ can affect cell growth and metabolism, seriously reducing the number of living cells. This is probably because NPs are recognized as foreign bodies, and the exogenous substances block cell endocytosis and metabolism.

We selected $20 \mu \mathrm{g} / \mathrm{mL}$ as the test concentration to observe the effect of coculture time with different types of $\mathrm{TiO}_{2}$ NPs on osteoblast differentiation and intracellular mineralization. The results showed that at short coculture times, the NPs had little effect on osteoblasts, but when the coculture time was prolonged to 7 or $14 \mathrm{~d}$, it showed a significant difference. All experimental groups inhibited the expression of ALP, which means that $\mathrm{TiO}_{2}$ NPs inhibit the proliferation and differentiation of MC3T3-E1 cells, and anatase NPs inhibited the expression of ALP more than rutile NPs. The results of oxidative stress also indicated that $\mathrm{TiO}_{2}$ NPs can induce cells to produce ROS and superoxide, leading to cell apoptosis or necrosis. Some studies reveal that metallic ions have a significant influence on the cell cycle distribution of osteoblasts, inhibiting their proliferation and leaving most cells dormant [37, 38]. From the TEM micrograph of MC3T3-E1 cells, we can also see that NPs are prone to reuniting in the solution, then entering mitochondria after being swallowed, causing mitochondrial degeneration, necrosis, cavitation, and even an intracellular material leakage phenomenon which reduces the activity and differentiation ability of cells. At the same time, the apoptosis rate increased and the ALP expression was inhibited by $\mathrm{TiO}_{2}$ NPs, which reduce the vitality of osteoblasts. Thereafter, we can conclude that though $\mathrm{TiO}_{2}$ NPs can 


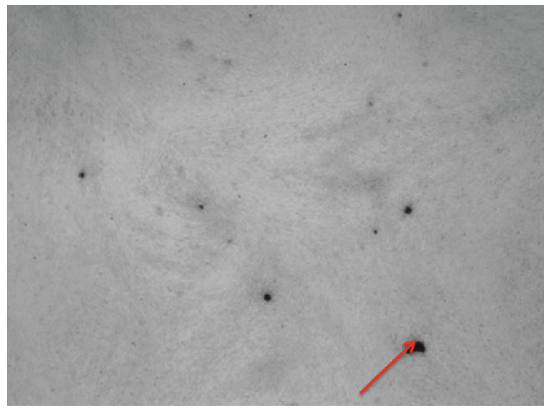

(a)

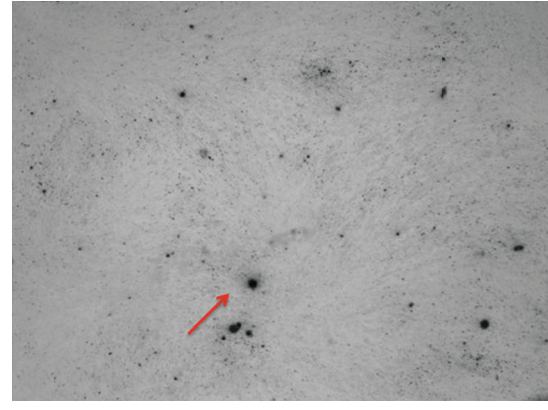

(b)

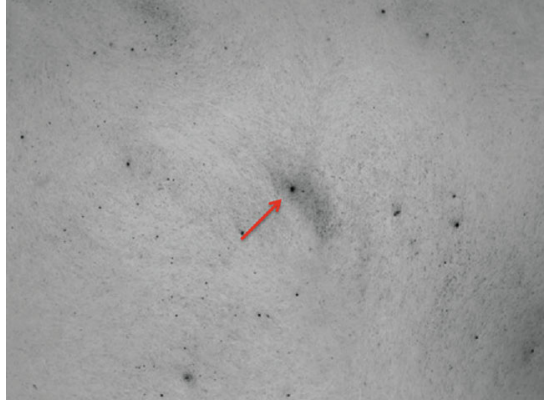

(c)

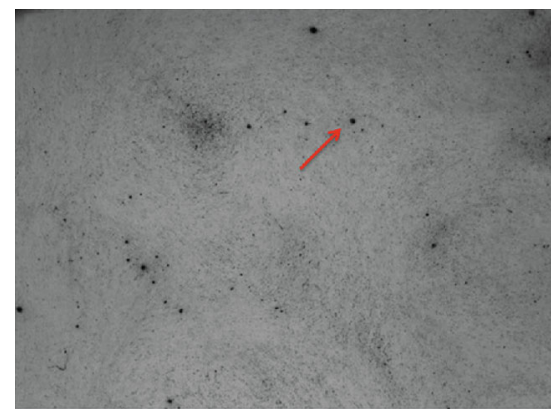

(d)

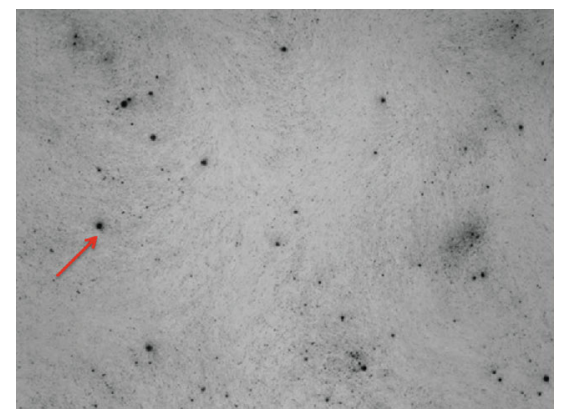

(e)

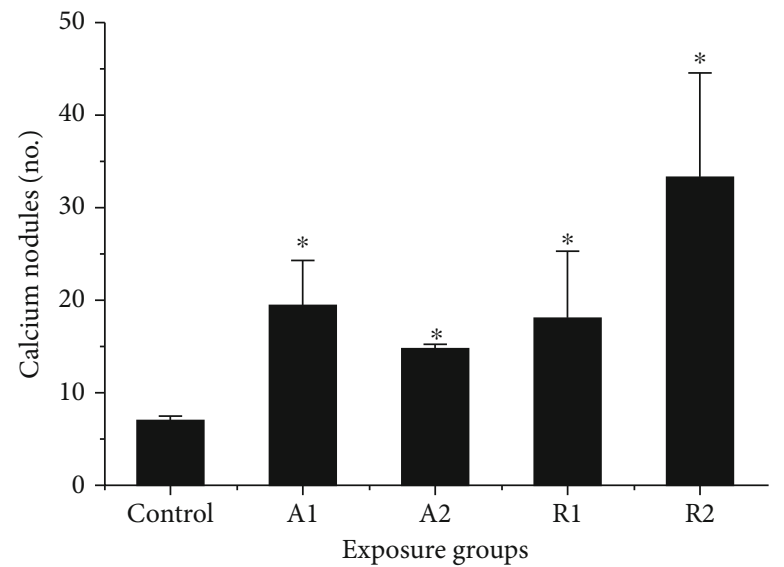

(f)

Figure 9: Alizarin Red S-stained mineralized nodules after coculture with differentiation medium for $28 \mathrm{~d}$ (arrows). There were more mineralized nodules in the experimental groups (b, c, d, e) compared with the control group (a). (f) Statistical graph of the quantity of mineralized nodules in different groups. There were significant differences between four experimental groups and the control group.

promote the maturation and mineralization of osteoblasts, they are not absolutely safe biomedical materials, and even a low dose of $20 \mu \mathrm{g} / \mathrm{mL}$ for short periods of stimulation has influence on cells.

\section{Conclusion}

$\mathrm{TiO}_{2}$ NPs have a certain negative influence on bone formation. Here, we find that all the concentrations, shapes, and coculture times of nano- $\mathrm{TiO}_{2}$ have different influence on the proliferation and differentiation of bone cells. In general, the presence of nano- $\mathrm{TiO}_{2}$ in tissues can accelerate cell senescence and apoptosis, leading to decreased osteoblast activity and obstructed bone formation.

\section{Data Availability}

The data used to support the findings of this study are available from the corresponding authors upon request.

\section{Conflicts of Interest}

The authors declare that they have no conflicts of interest.

\section{Authors' Contributions}

Yixing Ren and Xinxing Feng contributed equally to this work. 


\section{Acknowledgments}

This study was supported financially by the Shenzhen Science and Technology Project (JCYJ20170817140537062).

\section{Supplementary Materials}

Supplementary 1 Sedimentation of nano- $\mathrm{TiO}_{2}$ with different concentrations in PBS. Supplementary 2 Sedimentation of nano- $\mathrm{TiO}_{2}$ in $\mathrm{PBS}$ (the first 4 tubes) compared with that in MEM (the last tube) $\left(\mathrm{TiO}_{2}: \mathrm{BSA}=1: 40\right)$. Supplementary 3 The results of OCN measured by ELISA. There was no significant difference between the experimental groups and the control group. (Supplementary Materials)

\section{References}

[1] J. Jeevanandam, A. Barhoum, Y. S. Chan, A. Dufresne, and M. K. Danquah, "Review on nanoparticles and nanostructured materials: history, sources, toxicity and regulations," Beilstein Journal of Nanotechnology, vol. 9, pp. 1050-1074, 2018.

[2] H. Shi, R. Magaye, V. Castranova, and J. Zhao, "Titanium dioxide nanoparticles: a review of current toxicological data," Particle and Fibre Toxicology, vol. 10, no. 1, p. 15, 2013.

[3] S. Silva, H. Oliveira, A. M. S. Silva, and C. Santos, "The cytotoxic targets of anatase or rutile + anatase nanoparticles depend on the plant species," Biologia Plantarum, vol. 61, no. 4, pp. 717-725, 2017.

[4] A. Hasan, M. Morshed, A. Memic, S. Hassan, T. Webster, and H. Marei, "Nanoparticles in tissue engineering: applications, challenges and prospects," International Journal of Nanomedicine, vol. Volume 13, pp. 5637-5655, 2018.

[5] X. Li, J. Wei, K. E. Aifantis et al., "Current investigations into magnetic nanoparticles for biomedical applications," Journal of Biomedical Materials Research Part A, vol. 104, no. 5, pp. 1285-1296, 2016.

[6] A. Jimeno-Romero, M. Oron, M. P. Cajaraville, M. Soto, and I. Marigomez, "Nanoparticle size and combined toxicity of $\mathrm{TiO}_{2}$ and DSLS (surfactant) contribute to lysosomal responses in digestive cells of mussels exposed to $\mathrm{TiO}_{2}$ nanoparticles," Nanotoxicology, vol. 10, no. 8, pp. 1168-1176, 2016.

[7] T. H. Kim, M. S. Kang, N. Mandakhbayar, A. El-Fiqi, and H. W. Kim, "Anti-inflammatory actions of folatefunctionalized bioactive ion-releasing nanoparticles imply drug-free nanotherapy of inflamed tissues," Biomaterials, vol. 207, pp. 23-38, 2019.

[8] I. Pujalte, D. Dieme, S. Haddad, A. M. Serventi, and M. Bouchard, "Toxicokinetics of titanium dioxide $\left(\mathrm{TiO}_{2}\right)$ nanoparticles after inhalation in rats," Toxicology Letters, vol. 265, pp. 77-85, 2017.

[9] S. Vial, R. L. Reis, and J. M. Oliveira, "Recent advances using gold nanoparticles as a promising multimodal tool for tissue engineering and regenerative medicine," Current Opinion in Solid State \& Materials Science, vol. 21, no. 2, pp. 92-112, 2017.

[10] K. Zhang, Y. Fan, N. Dunne, and X. Li, "Effect of microporosity on scaffolds for bone tissue engineering," Regenerative Biomaterials, vol. 5, no. 2, pp. 115-124, 2018.

[11] A. J. Haider, Z. N. Jameel, and I. H. M. Al-Hussaini, "Review on: titanium dioxide applications," Energy Procedia, vol. 157, pp. 17-29, 2019.
[12] M. H. Hamzah, S. Eavani, and E. Rafiee, "CoAl2O4/TiO2 nano composite as an anti-corrosion pigment," Materials Chemistry and Physics, vol. 242, p. 122495, 2020.

[13] I. Narkevica, L. Stradina, L. Stipniece, E. Jakobsons, and J. Ozolins, "Electrophoretic deposition of nanocrystalline $\mathrm{TiO}_{2}$ particles on porous $\mathrm{TiO}_{2-\mathrm{x}}$ ceramic scaffolds for biomedical applications," Journal of the European Ceramic Society, vol. 37, no. 9, pp. 3185-3193, 2017.

[14] T. V. S. S. P. Sashank, B. Manikanta, and A. Pasula, "Fabrication and experimental investigation on dye sensitized solar cells using titanium dioxide nano particles," Materials Today: Proceedings, vol. 4, no. 2, pp. 3918-3925, 2017.

[15] J. Ferin, G. Oberdörster, and D. P. Penney, "Pulmonary retention of ultrafine and fine particles in rats," American Journal of Respiratory Cell and Molecular Biology, vol. 6, no. 5, pp. 535542, 1992.

[16] R. Kumazawa, F. Watari, N. Takashi, Y. Tanimura, M. Uo, and Y. Totsuka, "Effects of $\mathrm{Ti}$ ions and particles on neutrophil function and morphology," Biomaterials, vol. 23, no. 17, pp. 3757-3764, 2002.

[17] T. Brzicova, J. Sikorova, A. Milcova et al., "Nano- $\mathrm{TiO}_{2}$ stability in medium and size as important factors of toxicity in macrophage-like cells," Toxicology In Vitro, vol. 54, pp. 178$188,2019$.

[18] M. Ibrahim, J. Schoelermann, K. Mustafa, and M. R. Cimpan, " $\mathrm{TiO}_{2}$ nanoparticles disrupt cell adhesion and the architecture of cytoskeletal networks of human osteoblast-like cells in a size dependent manner," Journal of Biomedical Materials Research Part A, vol. 106, no. 10, pp. 2582-2593, 2018.

[19] K. Hattori, K. Nakadate, A. Morii, T. Noguchi, Y. Ogasawara, and K. Ishii, "Exposure to nano-size titanium dioxide causes oxidative damages in human mesothelial cells: the crystal form rather than size of particle contributes to cytotoxicity," Biochemical and Biophysical Research Communications, vol. 492, no. 2, pp. 218-223, 2017.

[20] M. J. Bessa, C. Costa, J. Reinosa et al., "Toxicity of rutile $\mathrm{TiO}_{2}$ nanoparticles immobilized in nanokaolin nanocomposites on $\mathrm{HepG}_{2}$ cell line," Toxicology and Applied Pharmacology, vol. 316, pp. 114-122, 2017.

[21] V. Madhubala, A. Pugazhendhi, and K. Thirunavukarasu, "Cytotoxic and immunomodulatory effects of the low concentration of titanium dioxide nanoparticles $\left(\mathrm{TiO}_{2} \mathrm{NPs}\right)$ on human cell lines-an in vitro study," Process Biochemistry, vol. 86, pp. 186-195, 2019.

[22] P. Kumar, "Nano-TiO2Doped chitosan scaffold for the bone tissue engineering applications," International Journal of Biomaterials, vol. 2018, Article ID 6576157, 7 pages, 2018.

[23] M. Dang, L. Saunders, X. Niu, Y. Fan, and P. X. Ma, "Biomimetic delivery of signals for bone tissue engineering," Bone Research, vol. 6, no. 1, p. 25, 2018.

[24] F. Gao, Z. Xu, Q. Liang et al., "Osteochondral regeneration with 3D-printed biodegradable high-strength supramolecular polymer reinforced-gelatin hydrogel scaffolds," Advanced Science, vol. 6, no. 15, p. 1900867, 2019.

[25] F. Gao, Z. Xu, Q. Liang et al., "Direct 3D printing of high strength biohybrid gradient hydrogel scaffolds for efficient repair of osteochondral defect," Advanced Functional Materials, vol. 28, no. 13, 2018.

[26] Y. Huang, X. Niu, W. Song, C. Guan, Q. Feng, and Y. Fan, "Combined effects of mechanical strain and hydroxyapatite/collagen composite on osteogenic differentiation of rat bone 
marrow derived mesenchymal stem cells," Journal of Nanomaterials, vol. 2013, Article ID 343909, 7 pages, 2013.

[27] Y. Ma, N. Hu, J. Liu et al., "Three-dimensional printing of biodegradable piperazine-based polyurethane-urea scaffolds with enhanced osteogenesis for bone regeneration," ACS Applied Materials \& Interfaces, vol. 11, no. 9, pp. 9415-9424, 2019.

[28] F. Yang, X. Niu, X. Gu, C. Xu, W. Wang, and Y. Fan, “Biodegradable magnesium-incorporated poly(L-lactic acid) microspheres for manipulation of drug release and alleviation of inflammatory response," ACS Applied Materials \& Interfaces, vol. 11, no. 26, pp. 23546-23557, 2019.

[29] X. Zhai, C. Ruan, Y. Ma et al., “3D-bioprinted osteoblast-laden nanocomposite hydrogel constructs with induced microenvironments promote cell viability, differentiation, and osteogenesis both in vitro and in vivo," Advanced Science, vol. 5, no. 3, 2018.

[30] T. Du, X. Niu, S. Hou et al., "Highly aligned hierarchical intrafibrillar mineralization of collagen induced by periodic fluid shear stress," Journal of Materials Chemistry B, vol. 8, no. 13, pp. 2562-2572, 2020.

[31] X. Niu, S. Chen, F. Tian, L. Wang, Q. Feng, and Y. Fan, "Hydrolytic conversion of amorphous calcium phosphate into apatite accompanied by sustained calcium and orthophosphate ions release," Materials Science \& Engineering CMaterials for Biological Applications, vol. 70, Part 2, pp. 1120-1124, 2017.

[32] X. Niu, R. Fan, X. Guo et al., "Shear-mediated orientational mineralization of bone apatite on collagen fibrils," Journal of Materials Chemistry B, vol. 5, no. 46, pp. 9141-9147, 2017.

[33] X. Niu, R. Fan, F. Tian et al., "Calcium concentration dependent collagen mineralization," Materials Science \& Engineering C-Materials for Biological Applications, vol. 73, pp. 137-143, 2017.

[34] R. G. Tilkin, N. Regibeau, S. D. Lambert, and C. Grandfils, "Correlation between surface properties of polystyrene and polylactide materials and fibroblast and osteoblast cell line behavior: a critical overview of the literature," Biomacromolecules, vol. 21, no. 6, pp. 1995-2013, 2020.

[35] M. Sajid, M. Ilyas, C. Basheer et al., "Impact of nanoparticles on human and environment: review of toxicity factors, exposures, control strategies, and future prospects," Environmental Science and Pollution Research, vol. 22, no. 6, pp. 4122-4143, 2015.

[36] H. Zreiqat, T. N. Crotti, C. R. Howlett, M. Capone, B. Markovic, and D. R. Haynes, "Prosthetic particles modify the expression of bone-related proteins by human osteoblastic cells in vitro," Biomaterials, vol. 24, no. 2, pp. 337-346, 2003.

[37] C. E. Albers, W. Hofstetter, K. A. Siebenrock, R. Landmann, and F. M. Klenke, "In vitrocytotoxicity of silver nanoparticles on osteoblasts and osteoclasts at antibacterial concentrations," Nanotoxicology, vol. 7, no. 1, pp. 30-36, 2012.

[38] N. J. Hallab, C. Vermes, C. Messina, K. A. Roebuck, T. T. Glant, and J. J. Jacobs, "Concentration-and compositiondependent effects of metal ions on human MG-63 osteoblasts," Journal of Biomedical Materials Research, vol. 60, no. 3, pp. 420-433, 2002. 